\title{
Mapping Groundwater Quality Parameters Using Geographic Information System (GIS) in Oyo State, Nigeria
}

\author{
T. O. Ogunbode ${ }^{1^{*}}$ and I. P. Ifabiyi ${ }^{2}$ \\ ${ }^{1}$ Faculty of Basic Medical and Health Sciences, Bowen University, Iwo, Nigeria. \\ ${ }^{2}$ Department of Geography and Environmental Management, University of Ilorin, Nigeria.
}

Authors' contributions

This work was carried out in collaboration between both authors. Both authors read and approved the final manuscript.

Article Information

DOI: $10.9734 / J G E E S I / 2017 / 34634$

Editor(s):

(1) Wen-Cheng Liu, Department of Civil and Disaster Prevention Engineering, National United University, Taiwan and Taiwan Typhoon and Flood Research Institute, National United University, Taipei, Taiwan.

Reviewers:

(1) H. O. Nwankwoala, University of Port Harcourt, Nigeria (2) Dorota Porowska, University of Warsaw, Poland. Complete Peer review History: http://www.sciencedomain.org/review-history/20122

Original Research Article

Received $2^{\text {nd }}$ June 2017

Accepted $9^{\text {th }}$ July 2017

Published $19^{\text {th }}$ July 2017

\begin{abstract}
The knowledge of spatial pattern of groundwater quality is important to ensure a holistic approach to the management of the resource quality status in space and time. Thus a sample each of underground water was collected from each of the selected 5 rural communities in each of the selected 25 out of the 33 LGAs in Oyo State for the purpose of quality assessments. Eleven (11) parameters namely water temperature $\left({ }^{\circ} \mathrm{C}\right), \mathrm{pH}$, electr ical conductivity $(\mathrm{EC})$, Sodium $\left(\mathrm{Na}^{+}\right), \mathrm{SO}_{4}$, Potassium $\left(\mathrm{K}^{+}\right)$, Nitrate $\left(\mathrm{NO}_{3}\right)$, Phosphate $\left(\mathrm{PO}_{3}\right)$, coli-form count, Oxidation Redox Potential (ORP) and Total Dissolved Solids (TDS) were subjected to standard laboratory analysis. The data was further subjected to analysis of variance and Duncan post-hoc test. ArcGIS version 10.1software was applied to generate maps to show the Duncan groupings of each of the quality parameters across the study area. Two (2) parameters namely $\mathrm{pH}$ and sulphate show homogenous distribution while the other nine (9) parameters are heterogeneous. Descriptive analysis showed that the groundwater in the study area is generally fit for human consumption. However, adequate attention needs to be given to temperature and potassium contents because they both slightly exceeded the
\end{abstract}


standard required. The mapping affords spatial understanding of the distributional pattern of the parameters so that appropriate water quality management measure/s can be taken at a minimised cost to ensure appropriate levels of the parameter in the water to safeguard human health. Repeated investigation is required to determine the regularity or otherwise pattern of the water quality parameters.

Keywords: GIS; mapping; Oyo State; water quality; water management.

\section{INTRODUCTION}

Mapping spatial phenomena is salient to the understanding of geographic studies. Several attempts have been made to map spatial phenomena in geography and in other related disciplines. For instance [1,2,3,4] carried out water poverty mapping in their areas of study, the works that enable better understanding of spatial water scarcity with less stress while [5] integrated water quality index with geographic information system (GIS) for an effective interpretation of the quality status of a river. Mapping enables the location and fast understanding of other attributes of spatial phenomena. Mapping of water quality characteristics is still inadequate in water resource management as most of the existing works focus on the contents of quality parameters and at times its implications for human health having compared with the acceptable standards. However, a holistic understanding of water quality over space will help resource managers in taking holistic steps to either mitigate excessive occurrence of a parameter and/or widening the scope of our understanding of the status of water over an area $[6,7]$. Spatial mapping of water quality parameters enables affordable cost of ensuring the water resource management to enhance human health [8]. Examples of research in the areas of mapping water quality parameters be it surface or subsurface water resources include $[9,10,11]$. In the view of [9], groundwater is believed to be comparatively much clean and free from pollution than surface water. This view is in agreement with the observations of [12] and [13] where it was revealed that exploitation of underground water for domestic purposes is prominent in developing countries because of the susceptibility of surface sources to pollutants and also as a result of its fair quality. It was also emphasized that groundwater is less open to pollutants and when even contaminated water is introduced to the surface of the earth, it undergoes natural treatment in the course of infiltration before it replenishes or added to the antecedent groundwater.

However, constant awareness of the status of water is salient to human welfare as such will reveal the resource potability at a point in time and in space. According to $[14,7,15]$, the use of Geographic Information System (GIS) has grown rapidly in groundwater management and is now widely used to create digital geographic databases, to manipulate and prepare data as input for various model parameters and to display model output. The application of GIS as a tool has afforded the understanding of the spatial variation of ground water quality parameters. The objectives of this study are to assess the quality of groundwater; to determine its spatial pattern in the rural areas of Oyo State and to map the quality with the application of GIS technique.

\section{STUDY AREA}

Oyo state, located on latitude $079 \mathrm{~N}$ to $09 \mathrm{~N}$ and longitude $02.80^{\circ} \mathrm{E}$ and $4.50^{\circ} \mathrm{E}$, has its headquarters at Ibadan. It is bounded in the North by Kwara State, in the east by Osun State, in the South by Ogun State and in the West partly by Ogun State and partly by the Republic of Benin (Fig. 1).

Oyo State covers approximately an area of $28,454 \mathrm{~km}^{2}$ and is ranked fourteenth by size in the country. It has thirty-three (33) Local Goververnment Areas (LGAs). The total population as at 2006 census was 5,591,589 [16]. Some of the major urban centres include Ibadan, Ogbomoso, Oyo, Iseyin, Saki, Okeho among others.

The State is endowed with two seasons namely dry and wet seasons. Dry season starts from November to March while wet season starts from March and ends in October. Rainfall amount varies from an average of $1200 \mathrm{~mm}$ around Igbeti in the northern part of the State to 1800 $\mathrm{mm}$ in Igbo-Ora and Ibarapa zone in the 


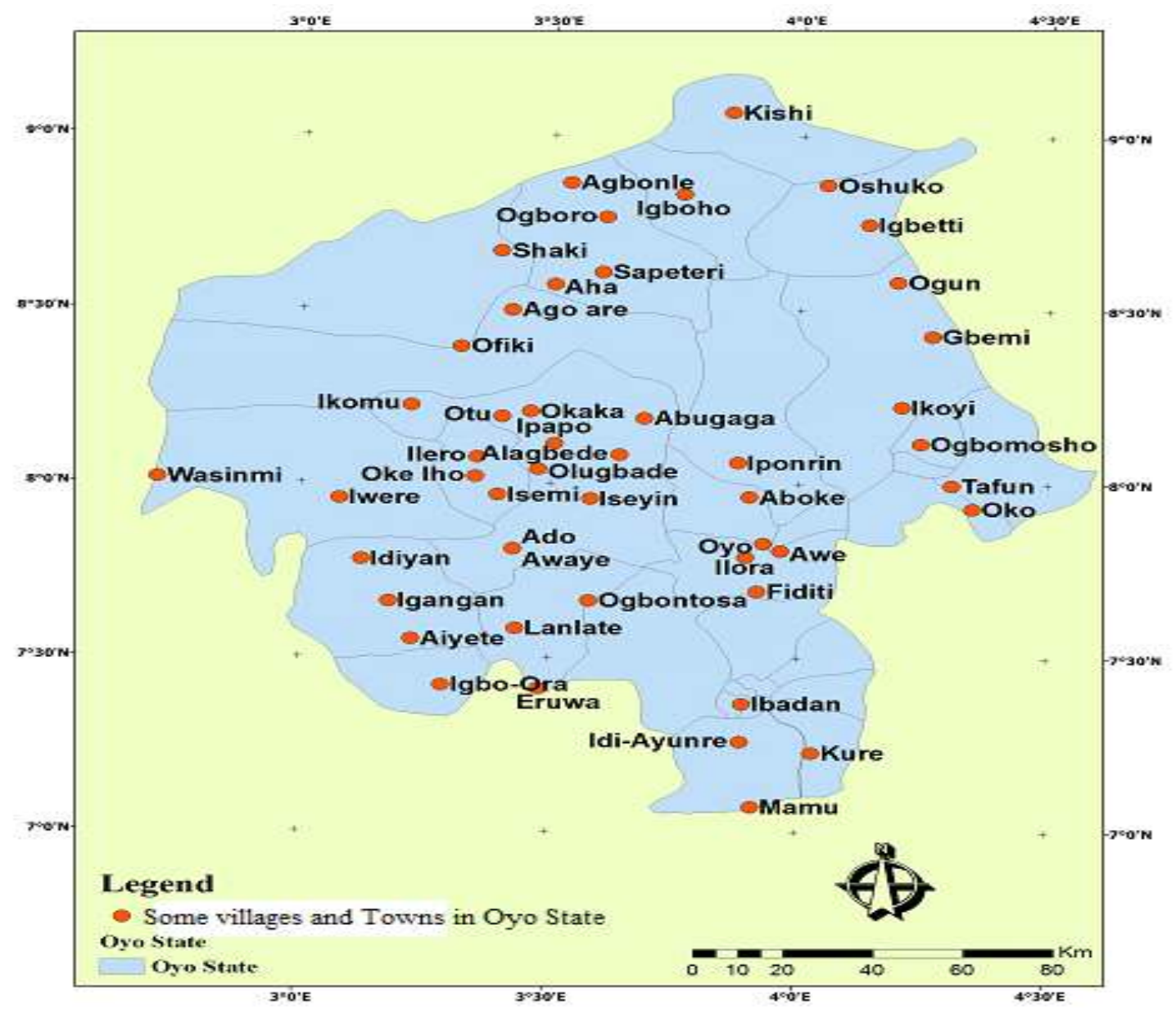

Fig. 1. Map of Oyo State showing some of the rural communities investigated

southern part. Water supply situation in Oyo state according to [17] is below any acceptable standard. The records from the Water Corporation, as revealed in the work, indicated that $233,485 \mathrm{~m} 3$ is generated daily by all water supply schemes in the state out of which about $55,080 \mathrm{~m} 3$ is actually supplied daily. The record further revealed that only $17.45 \%$ of households have piped water supply, but in Ibadan municipality $55 \%$ of households are linked to piped water supply. Thus over $56 \%$ of households in Oyo State have to obtain their water from unreliable sources. A report by [18] showed that preventable diseases are common. For example, schistosomiasis increased from 25 reported cases in 2003 to 1107 in 2005, cholera increased from 157 in 2004 to 2768 in 2005 and typhoid from 484 in 2003 to 10,432 in 2005 . Due to the susceptibility of surface water resources to contaminants [13], inhabitants in the rural areas who are hardly connected to pipe borne water networks often, as an alternative, resorted to subsurface sources through digging of wells and boreholes. It is worth noted that despite fair and better status of underground sources, cases of total abandonment of some wells or segrigation of some wells for certain purposes, according to [19], have been observed, the scenario being attributed to the physical, chemical and biological constituents of such underground sources.

\section{HYDROLOGEOLOGY}

Rocks of basement complex found in Oyo State include schists, associated with quartzite. The metamorphic rocks are largely undifferentiated, but two specific rock groups may still be identified [20,21]. The first group consists of migmatite complex, including banded magmatic and augen gneisses and pematites. Metasediments consisting of schists and quartzites, calsilicates, met conglomerates, 
amphibolites and metamorphic iron beds make up the second group (Fig. 2). Other parts of the State are underlain by undifferentiated metamorphic rocks.

The structural features that are important in hydrogeological thinking are difficult to elucidate in certain areas owing to the obliterating effect of migmatization [20,22]. According to [20], aquifers are of restricted vertical and lateral extent, but since the tropical climate affords the necessary conditions for deep and rapid chemical decay, thick, sandy clayey, lateritic overburdens serve as potential aquifers. Prediction of potential aquifers is possible using data on the thickness and lithology of the lateritic overburden on crystalline rocks [23].

\subsection{Data Collection and Analysis}

Water samples were obtained from underground sources such as hand-dug wells and boreholes from the selected five (5) villages in each of the twenty five (25) out of the thirty three (33) local government areas in the State for the purpose of water quality analysis (see Table 1). Samples were collected in a 2-litre plastic container which had been treated with 10 percent concentrated nitric acid for 48 hours to rid off every contaminants. These were labelled appropriately and sealed to avoid contamination before laboratory tests. The parameters that needed to be determined in-situ were taken especially water temperature, $\mathrm{pH}$ and electrical conductiviy. The analysis was carried out in the Departments of Chemistry and and that of Food Science and Technology, Bowen University, Iwo, Nigeria. The selection of eleven water quality parameters were partly based on the time frame for the work and laboratory facilities. Those examined include water temperature, $\mathrm{pH}$, electrical conductivity, Sodium $\left(\mathrm{Na}^{+}\right)$, Potassium $\left(\mathrm{K}^{+}\right)$, Nitrate $\left(\mathrm{NO}_{3}\right)$, Phosphate $\left(\mathrm{PO}_{3}\right)$, coli-form count, Oxidation Redox Potential (ORP) and Total Dissolved Solids (TDS).

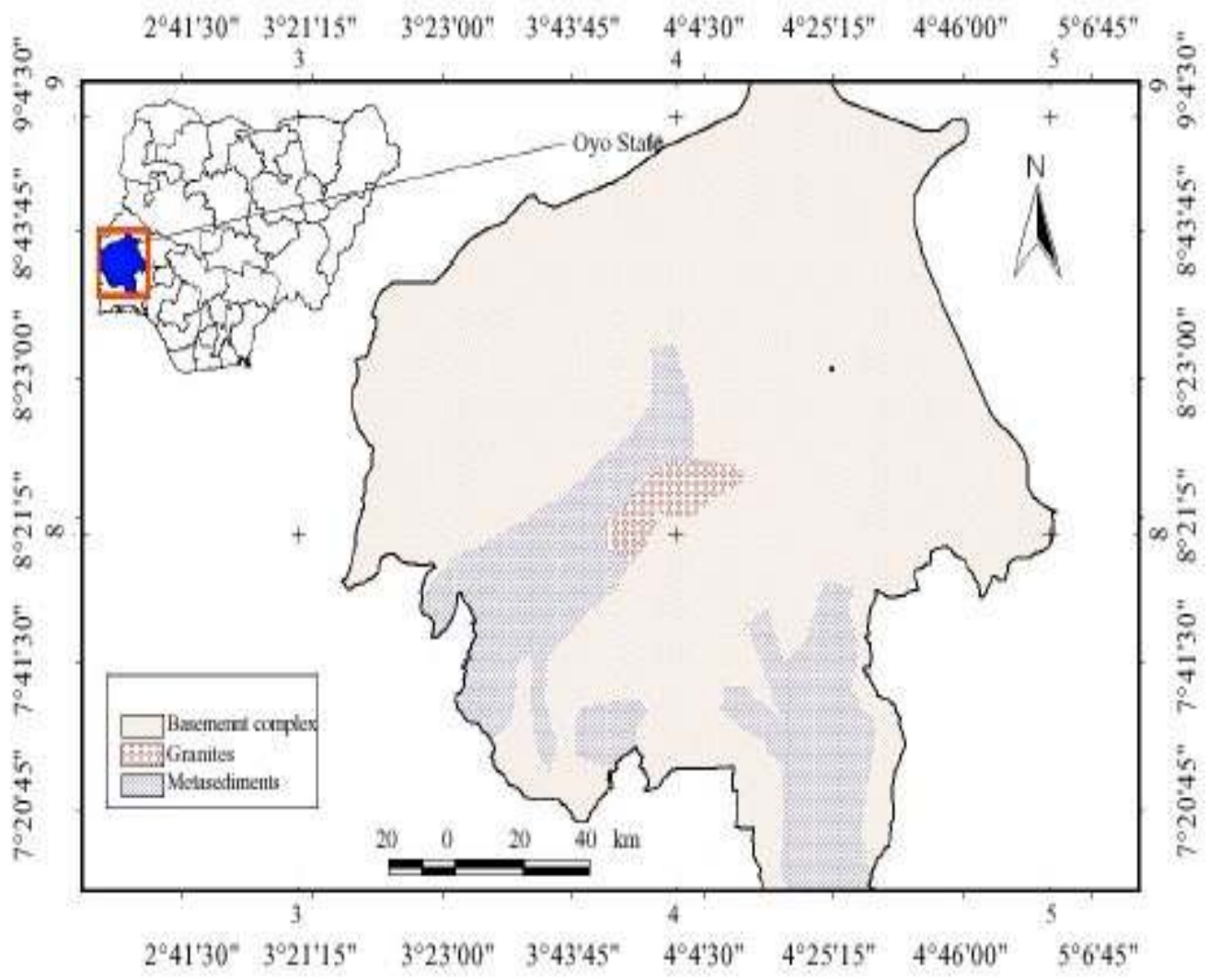

Fig. 2. Geological setting of Oyo State

(Source: [24]) 
Table 1. Descriptive pattern of water quality parameters in the rural areas of Oyo State

\begin{tabular}{|c|c|c|c|c|c|c|c|c|c|c|c|c|c|c|c|c|c|c|c|c|c|c|c|}
\hline \multirow[t]{2}{*}{$\mathbf{S} / \mathbf{N}$} & \multirow[t]{2}{*}{ LGA } & \multicolumn{2}{|c|}{$\mathrm{pH}$} & \multicolumn{2}{|c|}{ EC } & \multicolumn{2}{|c|}{$\mathrm{T}^{\circ} \mathrm{C}$} & \multicolumn{2}{|c|}{ TDS } & \multicolumn{2}{|c|}{ ORP } & \multicolumn{2}{|c|}{$\mathrm{NO}^{3}$} & \multicolumn{2}{|c|}{$\mathrm{PO}^{4}$} & \multicolumn{2}{|c|}{$\mathrm{SO}^{4}$} & \multicolumn{2}{|c|}{$\mathrm{Na}^{+}$} & \multicolumn{2}{|c|}{$\mathrm{K}^{+}$} & \multicolumn{2}{|c|}{ Coliform } \\
\hline & & $\overline{\mathbf{y}}$ & SD & $\overline{\mathbf{y}}$ & SD & $\overline{\mathbf{y}}$ & SD & $\overline{\mathbf{y}}$ & SD & $\overline{\mathbf{y}}$ & SD & $\overline{\mathbf{y}}$ & SD & $\overline{\mathbf{y}}$ & SD & $\overline{\mathbf{y}}$ & SD & $\overline{\mathbf{y}}$ & SD & $\overline{\mathbf{y}}$ & SD & & SD \\
\hline 1. & Afijio & 7.94 & 0.71 & 330.0 & 204.3 & 26.9 & 2.05 & 207.9 & 216.1 & 296.6 & 0.55 & 1.21 & 0.73 & 0.43 & 0.62 & 1.20 & 0.57 & 18.9 & 5.85 & 6.90 & 5.85 & 0.64 & 0.35 \\
\hline 2. & Akinyele & 7.78 & 0.51 & 300 & 220.3 & 27.4 & 1.67 & 203.4 & 55.4 & 293.4 & 0.55 & 1.38 & 0.57 & 1.18 & 0.44 & 0.67 & 0.27 & 21.9 & 4.67 & 8.40 & 2.52 & 0.29 & 0.28 \\
\hline 3. & Atisbo & 8.48 & 1.11 & 198.0 & 57.6 & 27.2 & 2.07 & 115.4 & 48.3 & 293.8 & 0.45 & 0.74 & 0.32 & 0.55 & 0.23 & 0.92 & 0.69 & 30.4 & 9.12 & 9.55 & 3.33 & 0.57 & 0.55 \\
\hline 4. & Egbeda & 8.58 & 0.73 & 588.0 & 185.7 & 23.8 & 0.51 & 481.4 & 173.3 & 294.0 & 0.90 & 1.58 & 0.52 & 0.70 & 0.24 & 1.05 & 0.59 & 24,3 & 9.43 & 7.60 & 3.14 & 1.07 & 0.46 \\
\hline 5. & Ibarapa Central & 8.50 & 0.57 & 206 & 61.1 & 26.8 & 2.03 & 248.2 & 110.3 & 293.8 & 0.45 & 0.87 & 0.32 & 0.63 & 0.40 & 1.07 & 1.06 & 29.4 & 5.56 & 11.9 & 1.86 & 1.09 & 0.86 \\
\hline 6. & Ibarapa East & 8.70 & 0.72 & 196.3 & 112.2 & 25.9 & 2.33 & 107.4 & 42.0 & 293.8 & 0.45 & 0.81 & 0.27 & 0.48 & 0.24 & 0.96 & 0.56 & 25.6 & 7.12 & 8.57 & 2.59 & 1.13 & 0.46 \\
\hline 7. & Ibarapa North & 8.54 & 0.90 & 232 & 60.6 & 26.0 & 2.43 & 184.1 & 79.0 & 293.8 & 0.45 & 1.31 & 0.67 & 0.34 & 0.69 & 1.28 & 0.98 & 27.6 & 9.84 & 9.95 & 1.30 & 1.39 & 0.61 \\
\hline 8. & Ido & 8.24 & 0.57 & 172 & 34.2 & 26.0 & 0.24 & 189.0 & 145.8 & 293.8 & 0.45 & 0.77 & 0.40 & 0.69 & 0.50 & 0.95 & 0.65 & 28.3 & 10.40 & 10.0 & 2.00 & 0.41 & 0.33 \\
\hline 9. & Irepo & 8.30 & 0.63 & 196 & 54.1 & 28.2 & 0.22 & 228.4 & 205.8 & 293.6 & 0.55 & 1.24 & 0.71 & 0.53 & 0.52 & 0.87 & 0.65 & 33.2 & 7.66 & 9.12 & 3.00 & 1.33 & 0.82 \\
\hline 10. & Iseyin & 7.46 & 0.70 & 268 & 139.4 & 26.0 & 2.39 & 209.1 & 200.9 & 293.8 & 0.45 & 1.33 & 0.65 & 0.79 & 0.53 & 1.12 & 0.54 & 27.9 & 8.51 & 9.81 & 3.22 & 0.84 & 0.37 \\
\hline 11. & Itesiwaju & 7.84 & 1.32 & 204.0 & 8.94 & 26.2 & 2.48 & 121.2 & 201.5 & 294.0 & 0.01 & 0.91 & 0.15 & 0.40 & 0.15 & 1.23 & 0.74 & 24.9 & 9.71 & 11.2 & 4.34 & 0.92 & 0.33 \\
\hline 12. & Iwajowa & 8.12 & 0.59 & 256.0 & 83.5 & 26.7 & 1.99 & 205.0 & 133.7 & 293.0 & 0.45 & 0.84 & 0.54 & 0.74 & 0.27 & 1.04 & 0.23 & 24.8 & 10.50 & 8.45 & 3.04 & 0.55 & 0.48 \\
\hline 13. & Kajola & 8.06 & 0.84 & 172.0 & 35.6 & 26.9 & 1.94 & 121. & 30.1 & 293.8 & 0.45 & 0.63 & 0.37 & 0.75 & 0.45 & 0.93 & 0.73 & 18.1 & 4.76 & 6.56 & 1.59 & 1.00 & 0.27 \\
\hline 14. & Lagelu & 8.04 & 0.98 & 614.0 & 117.4 & 23.8 & 0.31 & 487.7 & 117.3 & 290.8 & 4.44 & 1.49 & 0.89 & 0.63 & 0.25 & 0.74 & 0.18 & 21.8 & 3.98 & 5.65 & 1.83 & 0.06 & 0.02 \\
\hline 15. & Ogo-Oluwa & 7.90 & 0.28 & 254 & 111.5 & 23.4 & 0.09 & 169.7 & 92.7 & 293.6 & 0.55 & 1.04 & 0.41 & 0.67 & 0.33 & 1.11 & 0.59 & 33.8 & 11.50 & 10.5 & 3.15 & 0.66 & 0.29 \\
\hline 16. & Olorunsogo & 8.32 & 0.48 & 346.0 & 208.9 & 26.9 & 1.67 & 215.3 & 212.3 & 294.0 & 0.09 & 1.13 & 0.79 & 1.05 & 0.67 & 1.06 & 0.41 & 27.3 & 7.69 & 6.35 & 2.22 & 0.61 & 0.41 \\
\hline 17. & Oluyole & 8.51 & 1.05 & 214.0 & 33.6 & 26.8 & 1.96 & 168.2 & 40.5 & 293.6 & 0.55 & 0.92 & 0.23 & $0 . .78$ & 0.42 & 0.95 & 0.30 & 28.2 & 5.89 & 8.81 & 2.67 & 0.35 & 0.23 \\
\hline 18. & Ona-Ara & 7.86 & 0.74 & 226.0 & 32.1 & 25.1 & 2.40 & 115.3 & 54.3 & 294.0 & 0.09 & 1.08 & 0.35 & 0.74 & 0.39 & 1.50 & 0.48 & 19.7 & 4.47 & 7.16 & 1.91 & 0.21 & 0.26 \\
\hline 19. & Orelope & 7.98 & 0.59 & 222.0 & 82.9 & 27.7 & 0.89 & 107.8 & 49.1 & 294.0 & 0.09 & 0.70 & 0.35 & 0.98 & 0.28 & 1.17 & 0.50 & 25.4 & 9.90 & 7.61 & 1.58 & 0.80 & 0.73 \\
\hline 20. & Oriire & 8.72 & 0.64 & 348.0 & 11.0 & 23.4 & 0.05 & 242.3 & 100.5 & 292.6 & 2.19 & 0.77 & 0.27 & 0.61 & 0.15 & 1.59 & 0.74 & 22.3 & 9.06 & 9.01 & 1.51 & 1.21 & 0.66 \\
\hline 21. & Oyo East & 8.20 & 0.58 & 518.0 & 168.0 & 23.3 & 0.13 & 425.2 & 119.9 & 284 & 0.09 & 1.86 & 0.96 & 0.74 & 0.46 & 1.19 & 0.68 & 26.8 & 10.00 & 10.8 & 2.99 & 0.37 & 0.41 \\
\hline 22. & Oyo West & 8.66 & 1.03 & 418.0 & 222.0 & 23.4 & 0.07 & 90.1 & 83.4 & 291.8 & 1.30 & 1.02 & 0.30 & 0.65 & 0.40 & 08.9 & 0.22 & 26.6 & 7.90 & 7.8 & 5.40 & 0.20 & 0.20 \\
\hline 23. & Shaki East & 7.92 & 0.79 & 246.0 & 97.1 & 24.6 & 0.88 & 140.5 & 32.2 & 287.6 & 7.12 & 1.15 & 0.28 & 0.60 & 0.40 & 1.18 & 0.51 & 23.0 & 7.60 & 7.65 & 1.69 & 1.07 & 0.37 \\
\hline 24. & Shaki West & 8.48 & 0.52 & 406.0 & 270.7 & 24.9 & 1.90 & 306 & 226.4 & 291.2 & 6.26 & 1.33 & 0.92 & 0.77 & 0.27 & 1.08 & 0.41 & 25.1 & 10.40 & 10.9 & 3.48 & 1.08 & 0.66 \\
\hline 25. & Surulere & 8.44 & 0.73 & 186.3 & 105.6 & 23.5 & 0.31 & 142.5 & 33.6 & 293.6 & 0.55 & 0.75 & 0.36 & 0.54 & 0.25 & 1.21 & 0.42 & 21.6 & 3.46 & 9.80 & 1.27 & 0.30 & 0.36 \\
\hline \multirow{2}{*}{\multicolumn{2}{|c|}{$\begin{array}{l}\text { WHO } \\
\mathrm{NIS}^{* *}\end{array}$}} & \multirow{2}{*}{\multicolumn{2}{|c|}{$\begin{array}{l}6.5-8.5 \\
6.5-8.5\end{array}$}} & \multirow{2}{*}{\multicolumn{2}{|c|}{$\begin{array}{l}1000 \mu / \mathrm{cm} \\
1000 \mu / \mathrm{cm}\end{array}$}} & \multirow{2}{*}{\multicolumn{2}{|c|}{$\begin{array}{l}25^{\circ} \mathrm{C} \\
25^{\circ} \mathrm{C}\end{array}$}} & \multirow{2}{*}{\multicolumn{2}{|c|}{$\begin{array}{l}600 \mathrm{mg} / \mathrm{L} \\
500 \mathrm{mg} / \mathrm{L}\end{array}$}} & \multirow{2}{*}{\multicolumn{2}{|c|}{$\begin{array}{l}\text { NA } \\
\text { NA }\end{array}$}} & \multirow{2}{*}{\multicolumn{2}{|c|}{$\begin{array}{l}50 \mathrm{~ms} / \mathrm{L} \\
50 \mathrm{~ms} / \mathrm{L}\end{array}$}} & \multirow{2}{*}{\multicolumn{2}{|c|}{$\begin{array}{l}2.2 \mathrm{mg} / \mathrm{L} \\
\mathrm{NA}\end{array}$}} & \multirow{2}{*}{\multicolumn{2}{|c|}{$\begin{array}{l}250 \mathrm{mg} / \mathrm{L} \\
100 \mathrm{mg} / \mathrm{L}\end{array}$}} & \multirow{2}{*}{\multicolumn{2}{|c|}{$\begin{array}{l}200 \mathrm{mg} / \mathrm{L} \\
200 \mathrm{mg} / \mathrm{L}\end{array}$}} & $10 \mathrm{~ms}$ & & $10 / 10$ & \\
\hline & & & & & & & & & & & & & & & & & & & & NA & & $10 \mathrm{cft}$ & \\
\hline
\end{tabular}


The qualities of water samples taken from each of the villages were assessed for physicochemical and bacteriological parameters.

\subsection{Quality Control Measures}

\subsubsection{Sterilisation of apparatus}

The plastic bottles meant for sampling were treated with non -ionic detergent, rinsed with tap water and then soaked in 10 percent concentrated $\mathrm{HNO}_{3}$ for 48 hours prior to sampling for chemical analyses. Containers were thereafter rinsed with distilled water and with well water being sampled.

\subsubsection{Reagents used and their sources}

All the reagents used were of analytical grade and the instruments were pre-calibrated appropriately prior to measurement. Among the reagents are methanol (Park scientific Ltd. Northampton, U.K); Nitric acid (BDH Laboratory supplies Poole, England); Sodium hydroxide (Merck, Kennzechung, Germany); $\mathrm{HCl}$ (BDH laboratory supplies, Poole, England); $\mathrm{H}_{2} \mathrm{SO}_{4}$ (BDH laboratory supplies, Poole, England); KI (Park scientific Ltd. Northampton, U.K); Sodium azide (Kem Light laboratories PVT. Ltd. Mumbai, India); Sodium tetraborate (BDH laboratory supplies, Poole, England); Amberlite XAD - 16 resin (Aldrich, South Africa).

\subsubsection{Sample collection and handling}

About $2 \mathrm{~L}$ well water samples for bacteriological and physico-chemical parameter analyses were collected in each of the villages. All the samples, both for bacteriological and anions analysis were stored in the refrigerator at about $4^{\circ} \mathrm{C}$ to inactivate the bacteria and to prevent change in volume due to evaporation.

\subsection{Water Quality Mapping}

Arc GIS, Version 10.1 was used to generate maps that show the spatial distribution of the mean values of various water quality parameters in the study area and that of Duncan's groupings of the study area. This test enhances the reading and understanding of the spread of the variations in the quality of underground water in the rural areas of Oyo State. Analysis of variance (ANOVA) was carried out to determine the statistical difference among the mean concentrations of the parameters analysed. Posthoc test was further used to have in-depth understanding of the difference in the mean contents of the underground water quality parameters in Oyo State using Duncan's Multiple Range Test (MRT). Research works that have applied this post-hoc test include [25,26], and [27].

\section{RESULTS AND DISCUSSION}

Table 1 shows the mean contents $(\bar{y})$ of each parameter analysed and their respective standard deviation (SD).

Generally, the results revealed that the groundwater in the study area is generally fit for human consumption. However, adequate management attention needs to be paid to the temperature and the potassium contents of the water. It is noted that the maximum temperature recommended was slightly exceeded in Afijio, Akinyele, Atisbo, Ibarapa Central, Ibarapa East, Ibarapa North, Ido, Irepo, Iseyin, Itesiwaju, Iwajowa, Kajola, Olorunsogo, Oluyole, Orelope and Ona-Ara local government areas. The groundwater temperature ranges from $25.1^{\circ} \mathrm{C}$ in Ona-Ara LGA and $28.2^{\circ} \mathrm{C}$ in Irepo LGA. Also, the WHO acceptable content of potassium, $10 \mathrm{mg} / \mathrm{L}$, was exceeded in lbarapa Central $(11.9 \mathrm{mg} / \mathrm{L})$, Itesiwaju (11.2 mg/L), Ogo-Oluwa (10.5 mg/L) and Oyo East (10.8 mg/L).

Water quality mapping shown in Figs. 3 -13 was based on Duncan's Multiple Range Test (MRT) post-hoc test carried out. Duncan groups the study area based on the mean concentrations of the underground water quality parameters. The post-hoc test revealed that there were disparities in the mean values of most of the chemical parameters across the 25 local government areas except for $\mathrm{pH}$ and sulphate.

\subsection{Electrical Conductivity}

Seven regional patterns emerged for $E C$ as shown in Fig. 3. This suggests that EC is generally heterogeneous in the study area. Seven regional patterns described in the study area are: strongly high, moderately high, high, mildly high, low, moderately low and strongly low. Surface runoff has been noted to contribute to the EC contents in water. 


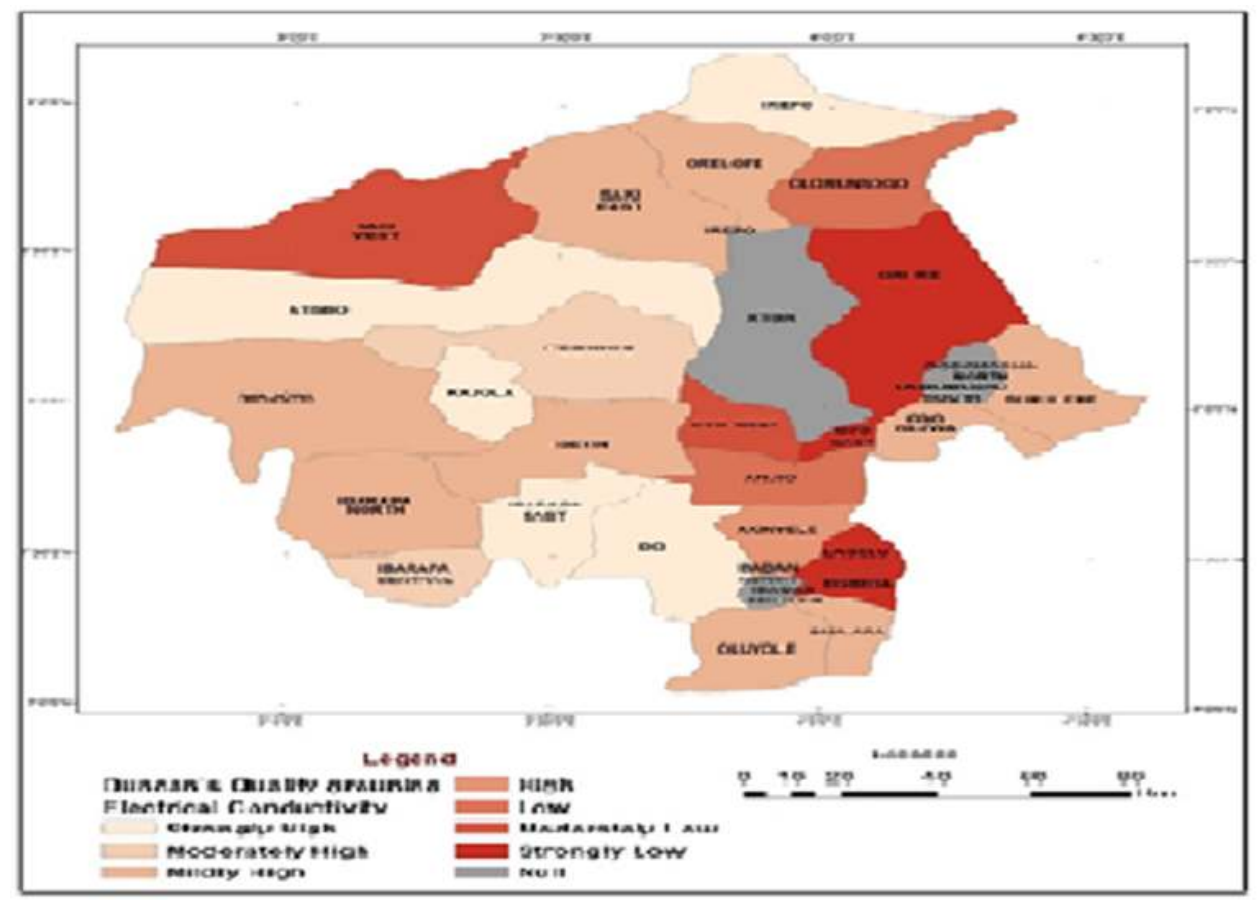

Fig. 3. Pattern of groundwater EC in Oyo State

\section{$4.2 \mathrm{pH}$}

Fig. 4 shows that $\mathrm{pH}$ has only one pattern as the results of the Duncan post-hoc test showed that they were not significantly different from one community to the other indicating the homogeneity of the source in the study area. This observation is in agreement with [25].

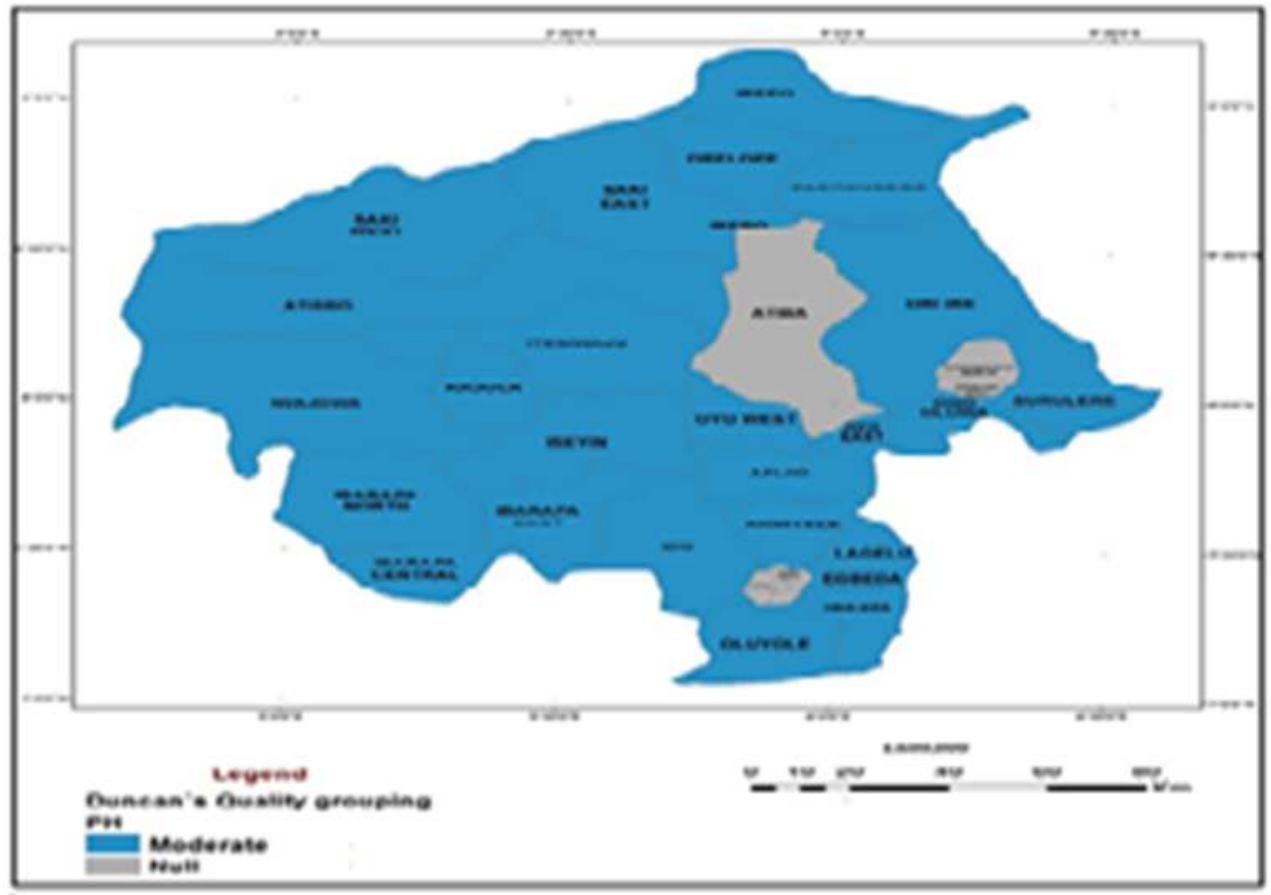

Fig. 4. Pattern of groundwater $\mathrm{pH}$ in Oyo State 


\subsection{Sodium}

Fig. 5 shows that sodium has only two regional pattern. These are mainly high and low regions. Sodium is high in concentration in 4 LGAs namely Kajola, Afijio, Ona-Ara and Oriire. However, in all other LGAs, the values of sodium is generally low. The results indicates that the degree of the variation in the content of the parameter is not high.

\subsection{Potassium}

Four regional patterns is discernable in the chemistry of potassium in the study area as revealed in Fig. 6. These are strongly high, moderately high, high and low regions due to the variations in the rock containing the parameter underground.

\subsection{Temperature}

Duncan post-hoc test showed that four regions emerged for temperature of underground water in the study area as presented in Fig. 7. These are strongly high, moderately high, high and low regions. The low regions include Oriire, Oyo East, Ogo-Oluwa, Ona-Ara, Orelope and Oyo West while Kajola only is found in the high region. This is due to the spatial variations in the climate change. [28] also observed that there is variability in water temperature in the study area.

\subsection{Total Dissolved Solids}

The test revealed that TDS are categorised into three regions namely moderately high, high and low as presented in Fig. 8. The LGAs in high region are Oriire, Oyo East, Egbeda and Lagelu while those in low regions include Ibarapa East, Oyo West, Orelope, Ona-Ara, Atisbo, Itesiwaju, Kajola, Shaki East, Surulere, Oluyole and OgoOluwa. This finding could be attributed to variations in surface wash that releases pollutants into the groundwater. The remaining LGAs are moderately high. The observed variability is also in support of the findings of [28].

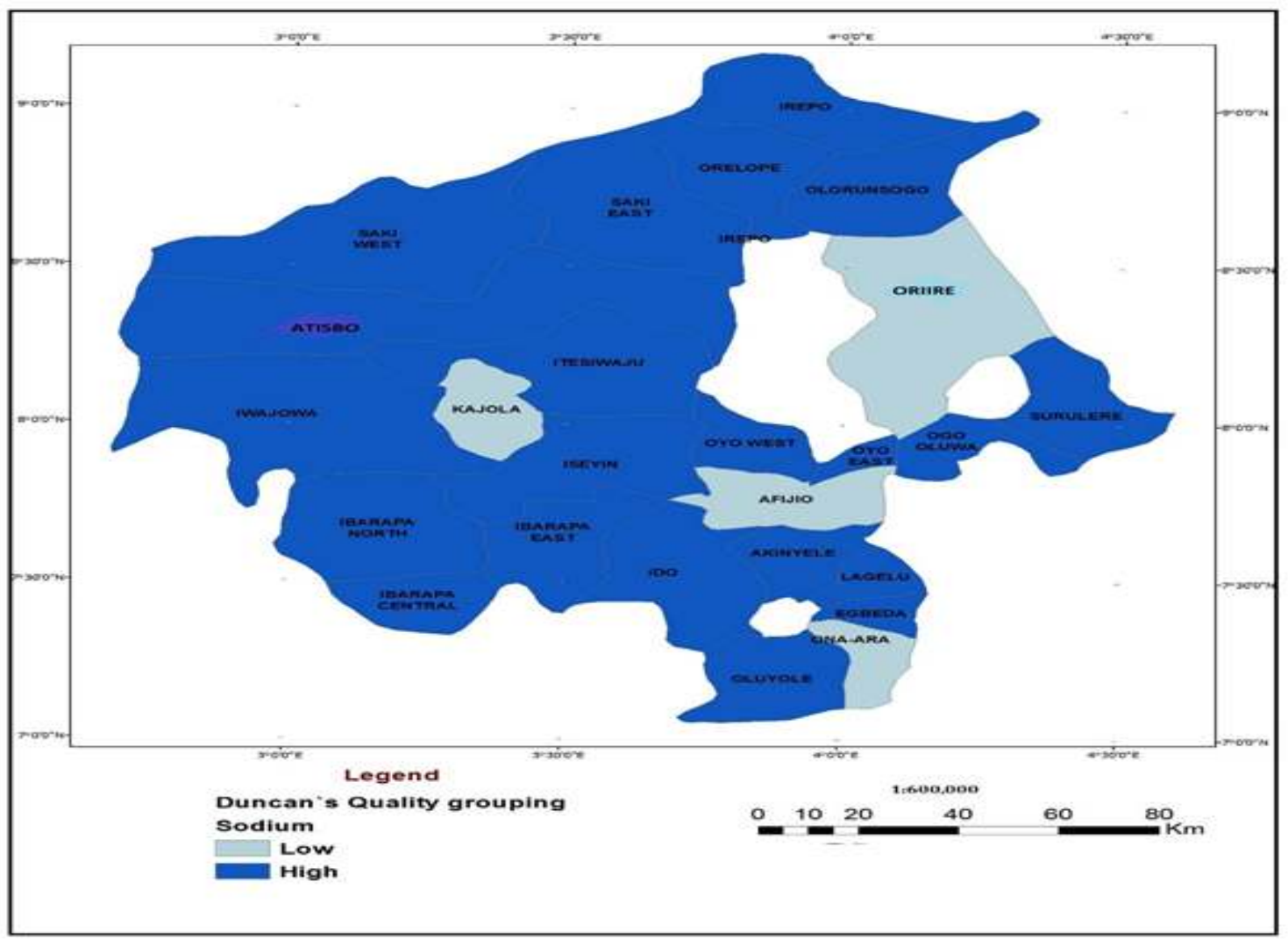

Fig. 5. Pattern of groundwater sodium in Oyo State 


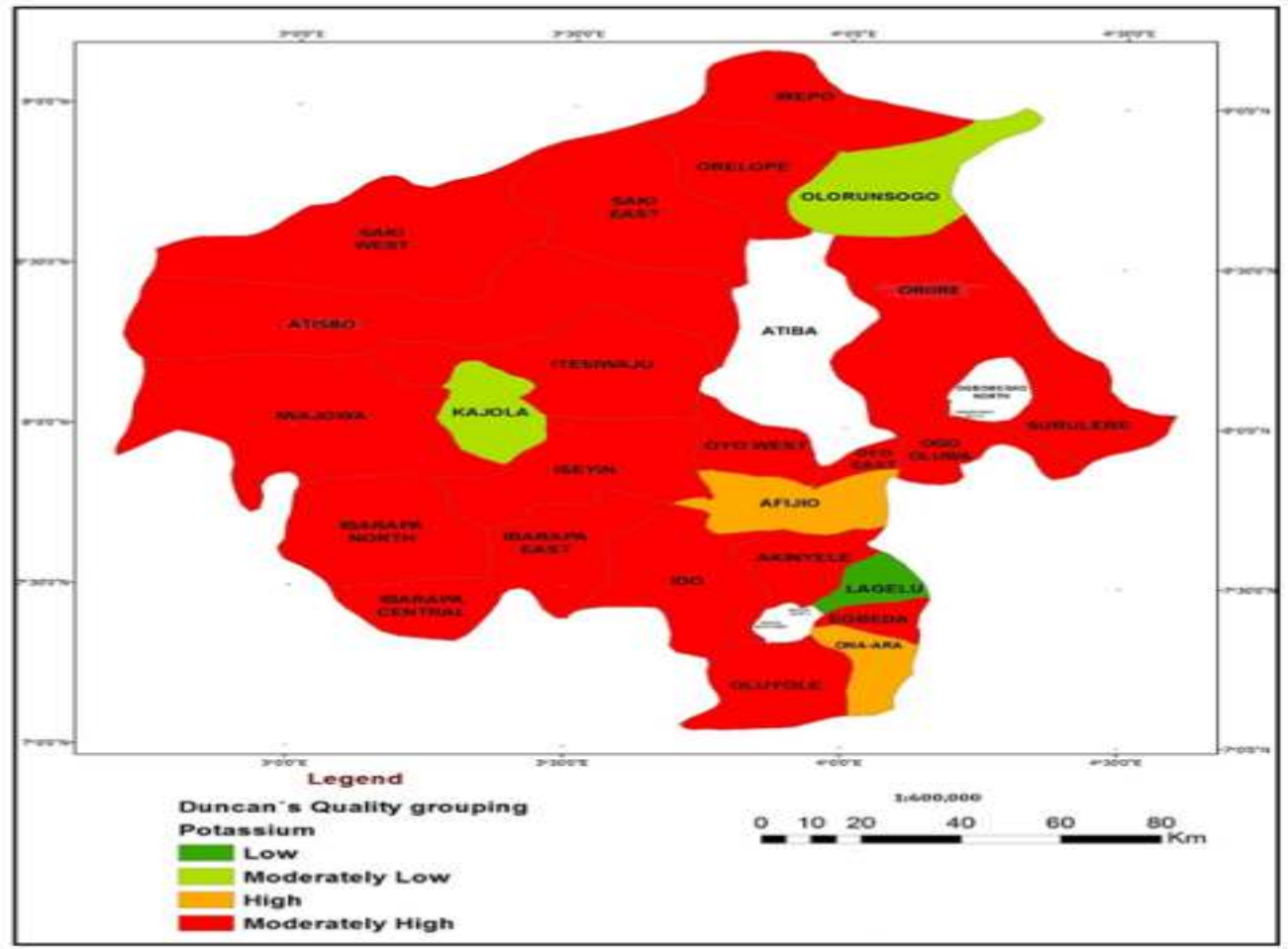

Fig. 6. Pattern of groundwater potassium in Oyo State

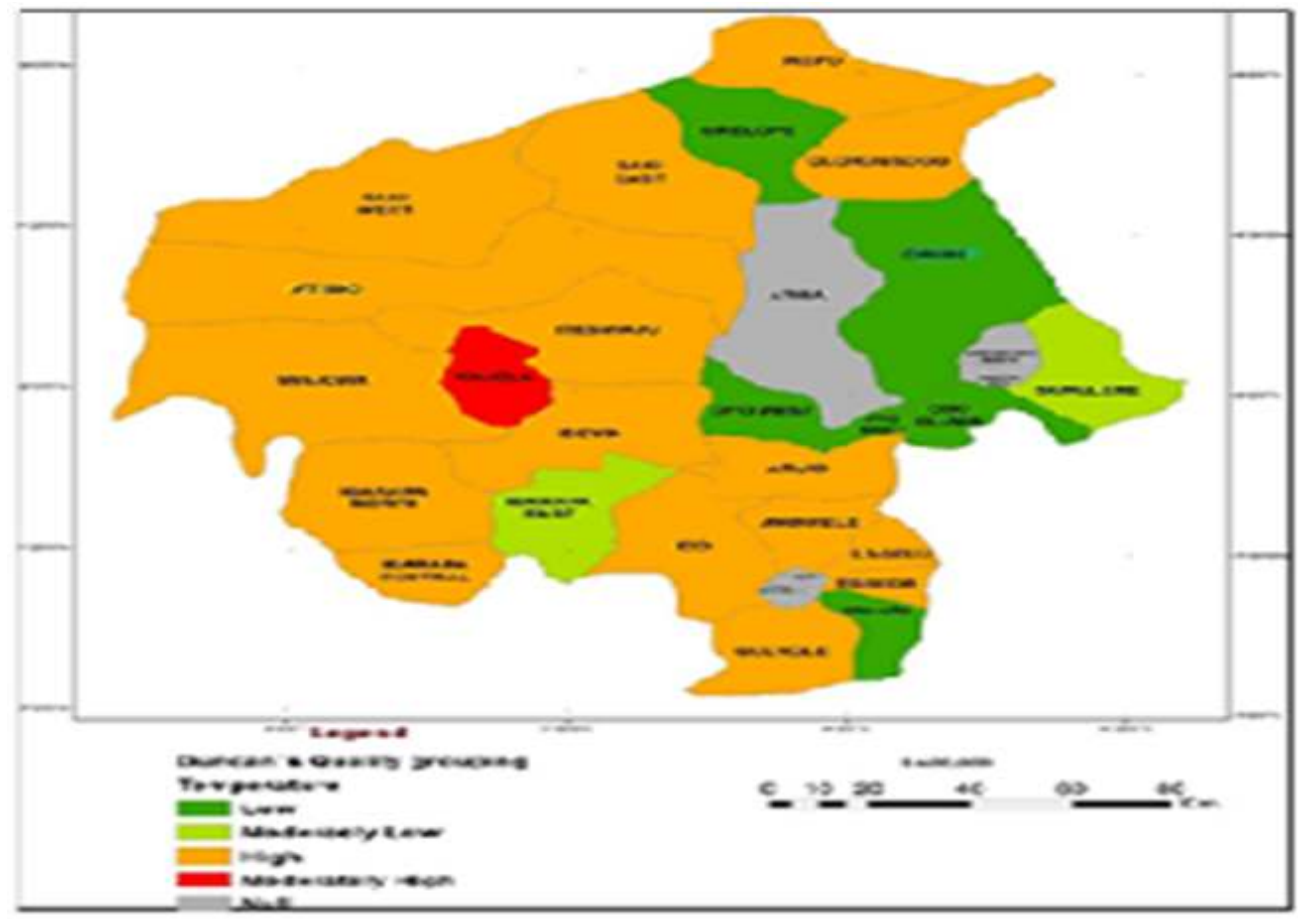

Fig. 7. Pattern of groundwater temperature in Oyo State 


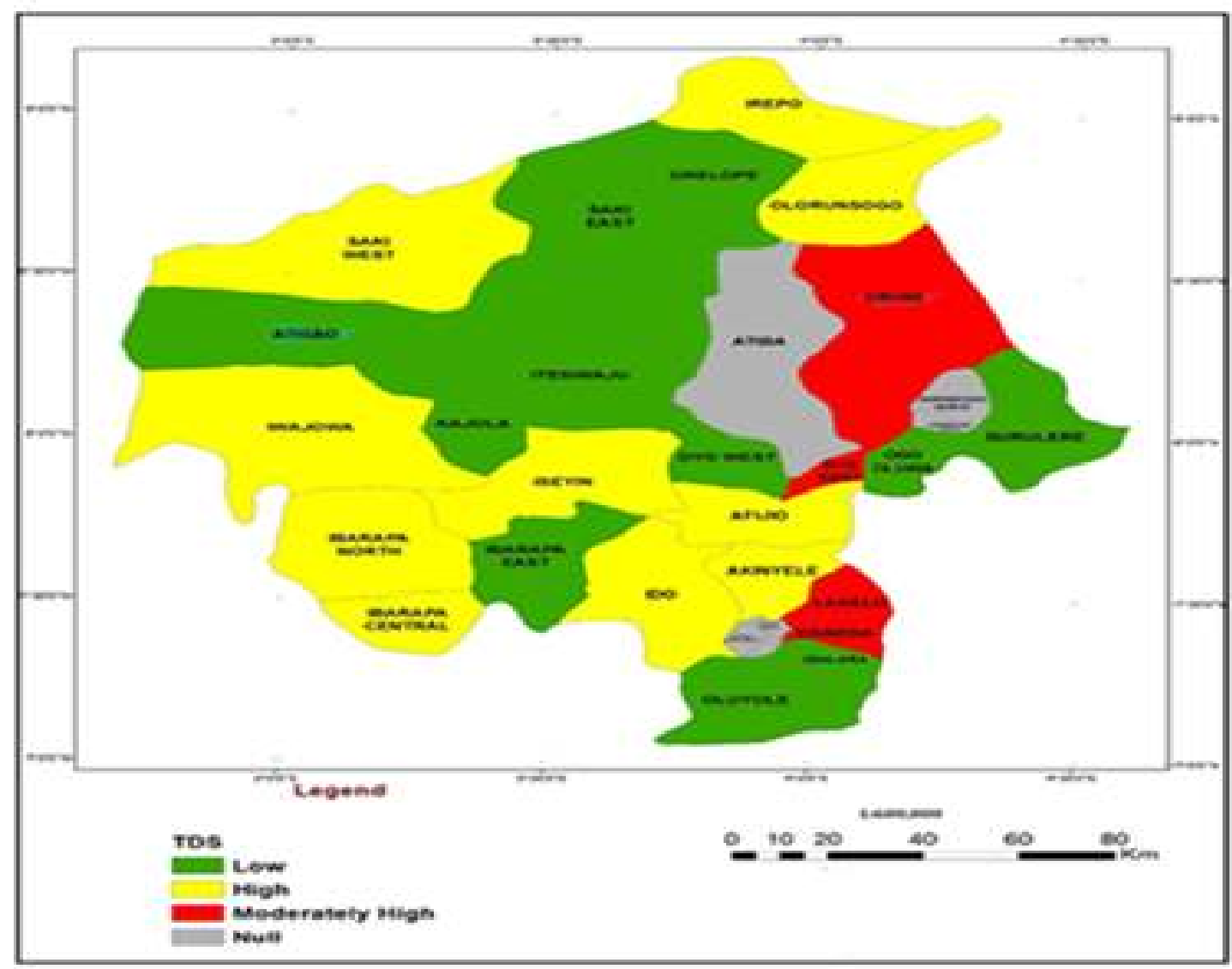

Fig. 8. Pattern of groundwater TDS in Oyo State

\subsection{Oxidation Redox Potential}

Fig. 9 revealed that three regional patterns also emerged for ORP in the study area. These are high, moderately high and low regions. Shaki East and Shaki West were respectively found in high and moderately high regions while the remaining 23 LGAs are in low regions.

\subsection{Nitrate}

Fig. 10 shows wide variation in the pattern of nitrate in the study area. The four regions that emerged are strongly high, moderately high, high and low regions. Kajola alone was found in the low region while Orelope and Ibarapa East emerged in high regions while the other LGAs are either strongly or moderately high. This is due to variation in the nitrate-rich rock. The result here is similar to [25] in which nitrate constituents of shallow wells was observed to have a wide variability.

\subsection{Phosphate}

The pattern of phosphate in the study area is similar to that of nitrate as 4 regional patterns equally emerged as shown in Fig. 11. This finding could be attributed to the variations in the underground rock. However, only Ibarapa North is in the low region while Itesiwaju, Afijio and Ibarapa East LGAs are in high region. Also, Irepo, Surulere, Atisbo and Shaki East are in moderately high region while other LGAs are in strongly high region.

\subsection{Sulphate}

The pattern of sulphate is similar to that of $\mathrm{pH}$ in the study area as the Duncan post-hoc test showed that the parameter is not significantly different across the 25 LGAs. Only one region emerged for this parameter as shown in Fig. 12. This is due to the variation in rock that contains sulphur underground. 




Fig. 9. Pattern of groundwater ORP in Oyo State

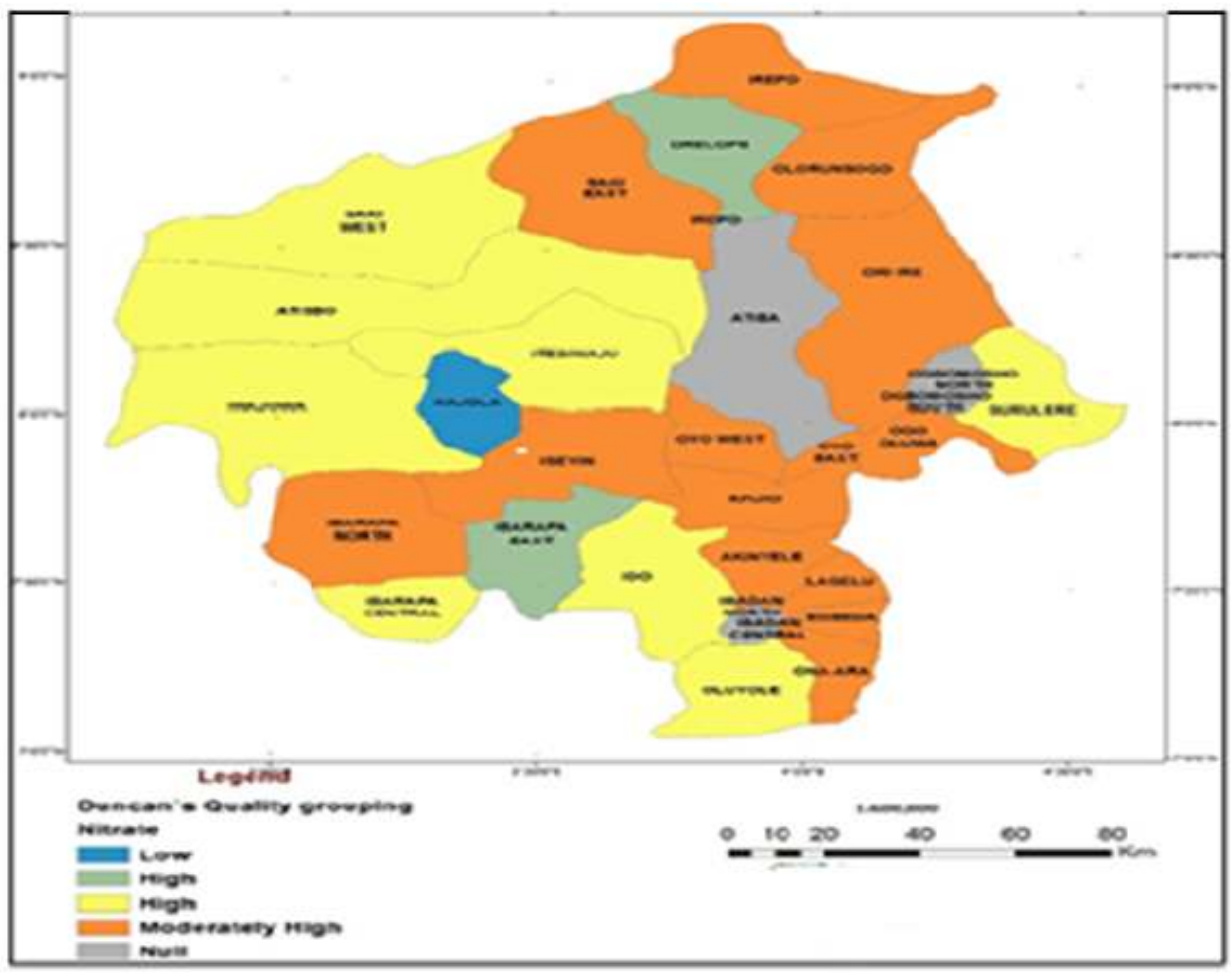

Fig. 10. Pattern of groundwater nitrate in Oyo State 


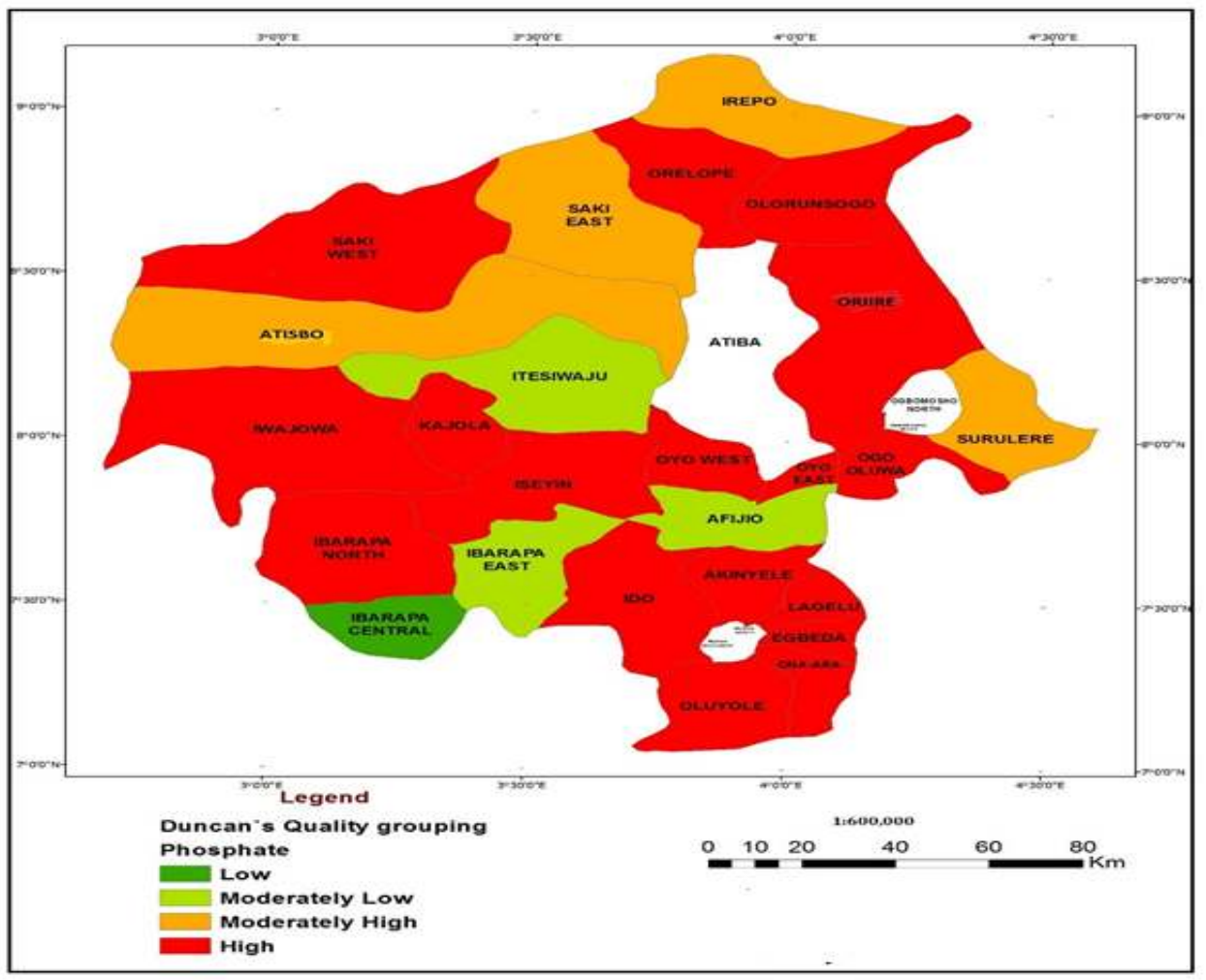

Fig. 11. Pattern of groundwater phosphate in Oyo State

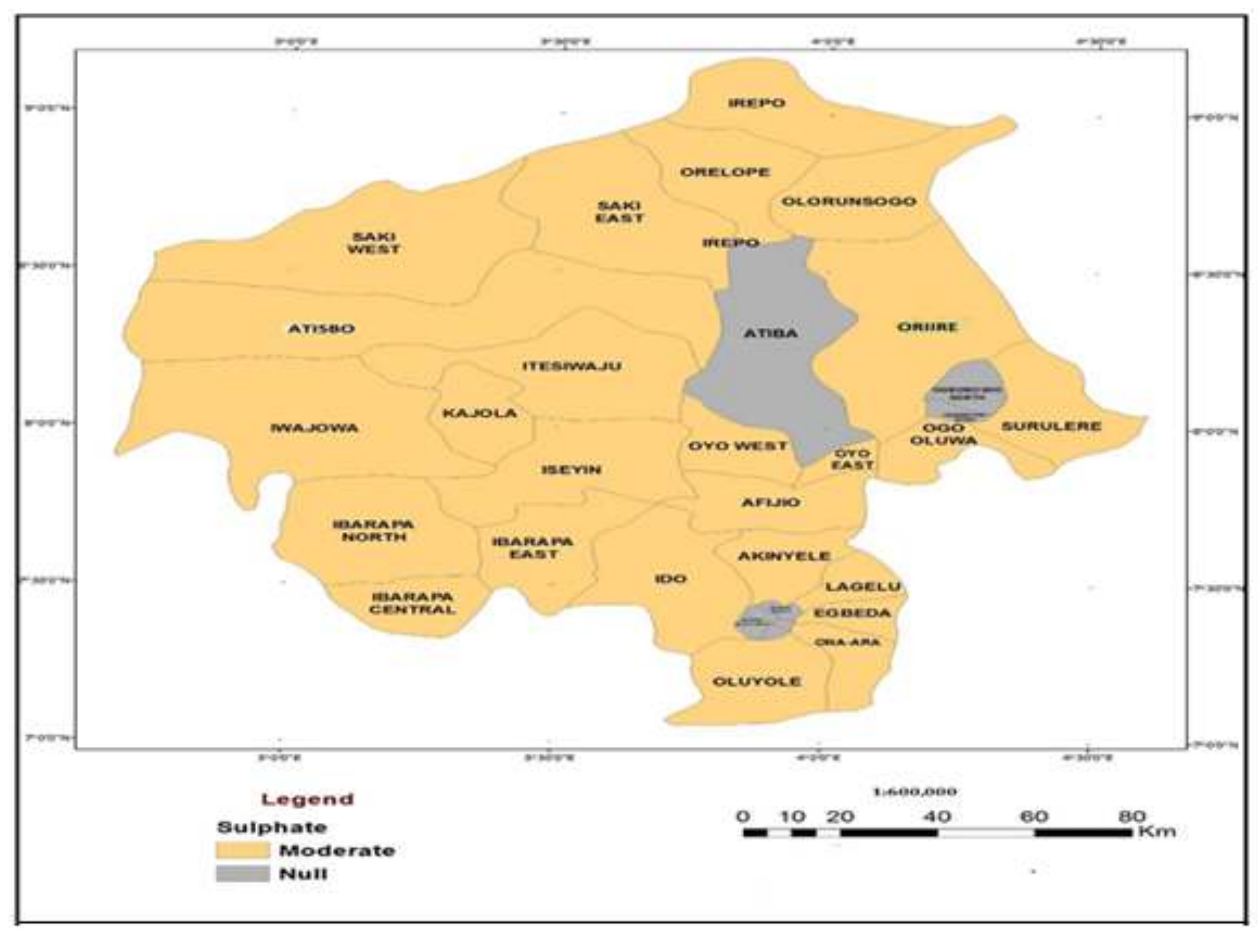

Fig. 12. Pattern of groundwater sulphate in Oyo State 




Fig. 13. Pattern of groundwater coliform counts in Oyo state

\subsection{Coliform}

Fig. 13 shows that the most widely varied parameter studied in the study area is coliform counts as the entire area have 9 regional patterns. Lagelu, Oyo West and Ona-Ara LGAs are grouped at the base of classification as strongly low region while 12 LGAs namely Orelope, Iseyin, Itesiwaju, Kajola, Shaki East, Egbeda, Shaki West, Ibarapa Central, Ibarapa East, Oriire, Irepo and Ibarapa North are at the peak of the classification, the strongly high region. The remaining LGAs are either moderately high, high, mildly high, low, moderately low or strongly low. This indicates the variation in the release of pollutants into groundwater especially human and animal faeces. This high level of variability, as discovered by [25], suggests the need for close monitoring of underground water quality in the study area.

\section{CONCLUSION}

The analysis of water quality reveals that the groundwater in the study area fits for human consumption, even though the temperature and potassium slightly exceeded the standard recommended. Also, an attempt was made to apply the GIS tool to map the spatial pattern of the groundwater quality parameter in the rural communities of Oyo State. The patterns of the parameters investigated as generated by Duncan's post-hoc test could assist relevant stakeholders in water quality management especially, in determining the relevant and proportion of holistic treatment that should apply to different communities and also, the time lag that such management could take. For instance, different management procedure and time lag may have to be applied to the control of bacteriological constituent in the study area due to its variability. The results showed that two 
parameters namely $\mathrm{pH}$ and sulphate are homogenous in their distribution while the remaining nine (9) parameters are heterogenous over the study area.

Several scholars have applied Duncan post-hoc test in water resource management especially in water quality studies. For instance, [25] noted that two properties ( $\mathrm{pH}$ and $\mathrm{Fe}^{+}$) do not significantly differ from one ward to the other while other properties including coliform differ significantly. [25] used the test to determine the significance level of the quality parameters of bottled water in Abeokuta, Nigeria. In the same vein, [29] applied Duncan multiple range test and found that there was no significant difference in the quality of harvested rainwater from roofs of different ages. So also, [26] used the test to determine the concentration of heavy metal in water and sediments.

\section{COMPETING INTERESTS}

Authors have declared that no competing interests exist.

\section{REFERENCES}

1. Cullis JDS. Water poverty mapping: Development and introduction using a case study at the local municipal scale for the Eastern Cape. Water Research Commission, TT 250/05; 2005.

2. van der Vyver C. Water poverty mapping and its management applications. Knowledge Management and Innovation: A Business Competitive Edge Perspective; 2010.

3. van der Vyver C, Jordaan D. The application of water poverty mapping in water management. The Journal for Trandisciplinary Research in Southern Africa. 2011;8(1):95-120.

4. Ifabiyi PI, Ogunbode TO. The use of composite water poverty index in assessing water scarcity in the rural areas of Oyo State, Nigeria. AFRREV STECHInternational Journal of Science and Technology. 2014;3(2):51-65.

5. Katyal D, Ahmed Qader A, Ismail AH, Sarma K. Water quality assessment of Yamuna River in Delhi region using index mapping. Interdisciplinary Environmental Review. 2012;13(2/3):170-186.

6. Aduan S, Iqbal J. Spatial analysis of the groundwater quality in the Peshawar
District, Pakistan. Procedia Engineering. 2014;70:14-20.

7. Danee JCS, Helen SM. Spatial mapping of groundwater quality using GIS. Int. J. Emerging Technology and Advan. Engineering. 2015;5(5):265-270.

8. Nas B, Berkley A. Groundwater quality mapping in urban groundwater using GIS. Environ. Monit. Assess. 2010;160(1-4): 215-227.

9. Balakrishnan P, Saleem A, Mallikarjun ND. Groundwater quality mapping using geographic information system (GIS): A case study of Gulbarga City, Karnataka, India. African J. Environmental Science and Technology. 2011;5(12):1069-1084.

10. Oke AO, Sangodoyin AY, Ogedengbe K, Omodele T. Mapping of river water quality using inverse distance weighted interpolation in Ogun-Oshun river basin, Nigeria. Landscape and Environment. 2013;7(2):48-62.

11. Mahagamage MGYL, Pathmalal MM. Mapping spatial distribution of water quality parameters using GIS in Groundwater of the Kelani River Basin, Sri Lanka. Proceedings of Academic World 12th International Conference, Singapore; 2015.

12. Thangavelu A. Mapping the groundwater quality in Coimbatore city, India, based on physic-chemical parameters. IOSR-J. Env. Sci., Toxicology and Food Technology (IOSR-JESTFT). 2013;3(4):32-40.

13. Ogunbode TO, Akintunde EA, Akinola TO. Assessment of underground water quality and water pollution sources apportionment in a growing urban centre in Osun State, Southwestern, Nigeria. European Journal of Geography. 2016;7(3):70-84.

14. Mahalingan B, Ramu M, Bhauso D, Jayashree P. Assessment of groundwater quality using GIS techniques: A case study of Mysore City. Int. J. Engineering and Innovative Technology (IJEIT). 2014;3(8): 117-122.

15. Khan SU, Noor A, Farooqi IH. GIS application for groundwater management and quality mapping in rural areas of District Agra, India. Int. J. Water Res. and Arid Env. 2015;4(1):89-96.

16. National Population Commission (NPC). Federal Government of Nigeria; 2006.

17. Kehinde MO, Longe EO. Providing water at affordable cost in developing economies: Towards millennium development goals. 29th WEDC International Conference, Abuja, Nigeria. 2003;248-250. 
18. National Bureau of Statistics (NBS); 2009.

19. Ogunbode TO. Domestic water utilisation and management in selected rural areas of Oyo State, Nigeria. PhD Thesis, Department of Geography, University of Ilorin, Nigeria. 2015;287.

20. Asseez OL. Rural water supply in the basement complex of Western State, Nigeria. Hydrological Sciences Bulletin. 1972;17:97-110.

21. Aderogba $\mathrm{K}$, Oderinde $\mathrm{F}$, Bakare $\mathrm{H}$. Spatial assessment of fresh water supply in Southwest Nigeria. Journal of Geography and Regional Planning. 2012;5(1):6-13.

22. Nwankwoala HO. Localizing the strategy for achieving rural water supply and sanitation in Nigeria. African Journal of Environmental Science and Technology. 2011;5(13):1170-1176.

23. Fasunwon OO, Ayeni AO, Lawal AO. A comparative study borehole water quality from sedimentary terrain and basement complex in Southwestern. Research Journal of Environmental Sciences. 2010;1-9.

24. Balogun OY. Senior secondary atlas. 2nd Edition. Longman, Nigeria; 2000.
25. Taiwo AM, Gbadebo AM, Awomeso JA. Potability assessment of selected brands of bottled water in Abeokuta, Nigeria. J. Applied Science \& Environmental Management. 2010;14(3):47-52.

26. Abegunrin TP, Sangodoyin AY, Odeniyi J, Onofua OE. Roof age effect on the quality of harvested rainwater and its health implication in a selected location, Southwest, Nigeria. International Journal of Water Resources and Environmental Engineering. 2014;6(10):261-266.

27. Ghasemi M, Moazed H. Determination of heavy metal in water and sediment of Dez River, Dezful, Khusestan Province, Iran. International Journal of Biosciences. 2014;4(2):232-238.

28. Fasae OA, Omolaja OE. Assessment of drinking water quality from different sources in small holder ruminant production in Abeokuta, Nigeria. Food Science and Quality Management. 2014;29:29-43.

29. Ifabiyi IP. Chemical characteristics of shallow wells in Ibadan North East L.G.A., Oyo State. Ilorin Journal of Business and Social Sciences. 2003;8(1\&2):119-126.

(c) 2017 Ogunbode and Ifabiyi; This is an Open Access article distributed under the terms of the Creative Commons Attribution License (http://creativecommons.org/licenses/by/4.0), which permits unrestricted use, distribution, and reproduction in any medium, provided the original work is properly cited.

Peer-review history:

The peer review history for this paper can be accessed here: http://sciencedomain.org/review-history/20122 